\title{
The Development of Writing Module on Enhancing the Writing Skills of Omani General Foundation Program Students
}

\author{
Moustafa Mohamed Abdelmohsen and Rohaya Abdullah \\ School of Educational Studies, University of Science Malaysia, Penang Malaysia \\ https://orcid.org/0000-0002-0963-4398 \\ https://orcid.org/0000-0003-4518-1733 \\ Yasir Azam \\ School of Humanities, University of Science Malaysia, Penang Malaysia \\ https://orcid.org/0000-0002-9411-4329
}

\begin{abstract}
This study aimed to investigate the effectiveness of a developed writing module on enhancing the General Foundation Program students' writing skills. The study made use of a pre-test and post-test quasi-experimental design. The study participants incorporated 70 Omani students and 2 EFL teachers. The students were divided into experimental and control groups. The experimental group incorporated 35 students who studied English at the General Foundation Program of Sur Nursing Institute. The control group involved 35 students who took an English course at The General Foundation Program Centre in Muscat. Both institutions function under the auspices of the Omani Ministry of Health. The control group studied the ministry's writing syllabus, whereas the experimental group studied the writing module. The writing pre-test was done before module delivery and the post-test was done after the intervention. ANCOVA test was utilized to draw a statistical analogy between the mean scores of tests of both groups. The test findings divulged that there was a statistically significant mean difference between the control and experimental group's scores in the writing post-test. The module significantly enhanced the experimental group's writing skills.
\end{abstract}

Keywords: Module; intervention; General Foundation Program; writing skills

\section{Introduction}

Writing is deemed a complicated and taxing cognitive task in which writers need to show mastery of variables simultaneously. These incorporate controls of sentence structure, format, content and vocabulary, and spelling. Additionally, writers have to be able to organize and combine information into a coherent and 
cohesive paragraph and text (Nunan, 2003). Writing is deemed one of the salient skills that learners need to master since it demands a more substantial in-depth knowledge of the grammar system and writing conventions than other receptive skills (Mourssi, 2013; Ellis, 2004). Writing is one of the most pivotal skills students must master in Oman (Al-Ani, 2017). Consequently, Omani students learn English at private and government colleges where the English syllabus aims to hone students' English language skills with an emphasis on writing (AlIssa, 2014). This is because writing is adjudged a crucial skill that Omani learners have to master to meet the requirements of higher education (Mourssi, 2013). The General Foundation Program of the Omani Ministry of Health is no exception. Writing is introduced as an extension for other English skills and subskills. The General Foundation Program writing syllabus adopts product and process approaches. These approaches are used at lower levels of English to guide students to mimic diversified model texts, brainstorm and organize ideas, and practice various writing features (Omani Ministry of Health-Foundation Program Course Overview, 2019). Despite the great effort that has been exerted by teachers to help the Foundation Program students sharpen their writing ability, the students face many problems in writing such as a lack of vocabulary knowledge, their inability to generate ideas, committing many spelling and grammar errors, and their inability to maintain paragraphs cohesion, coherence, and unity (Thyab, 2016; Abu-Faraj, 2015). The foundation program students commit many grammatical errors in their writing such as the wrong use of nouns, prepositions, adjectives, pronouns, verbs, word order, tenses, pronouns, subject-verb agreement, auxiliaries, and possessive pronouns (Sabtan \& Elsayed, 2019; Nouraey, Cuarteros, \& Khemiri, 2016; Alami, 2016). Further, students commit numerous spelling errors and they cannot use vocabulary appropriately (Al-Bereiki \& Al-Mekhlafi, 2015). Moreover, students make many punctuation errors such as the wrong use of question marks and capital letters, and commas (Ancheta \& Simagala, 2017). This results in a very poor writing production which negatively affects purpose and meaning and does not meet the foundation program writing criteria (Khalil \& Yassin, 2015). Hence, there was a dire need to develop a writing module that teaches to General Foundation Program students' learning needs and enhances their writing skills. The module development in this research was guided by the ADDIE model. ADDIE is a timesaving model and encourages effectual learning. Most importantly, the model helped ensure that learners achieve the module objectives giving room for the evaluation of learners' needs and also the efficacy of the module using procedures with certain outcomes that can be assessed.

\section{Theoretical Framework}

The present study is underpinned by the sociocultural theory of human learning (Vygotsky, 1978). The theory deems learning a social procedure. The prime abstraction of this theory is that social interplay significantly contributes to the progress of cognition. Vygotsky (1978) believes that there is an influential connection between learning and culturally organized experiences. The notion is very advantageous in learning and teaching since it addresses how learners' interaction becomes the most pivotal method by which learning and development take place. 
This theory is pertinent to the current study because it substantiates the fundamental significance of collaboration in the writing classroom where students exchange meaning, knowledge, and learn from peers. Thus, it can be inferred that students learn best when they collaborate with their peers (Saparuddin, Prasetyo \& Mahanal, 2018; Jeroen Janssen \& Wubbels, 2018; Bikowski \& Vithanage, 2016; Dowse \& Rensburg, 2015; Khatib, 2015; Nosratinia \& Nikpanjeh, 2015; Yeh, 2014). Since the study aimed to improve students' writing ability by adopting the genre approach, Vygotsky's theory is relevant to the study. It is relevant because it helps both teachers and students to engage in socially constituted interrelation opportunities to create and exchange knowledge via their social discourse. Writing in this study is a social activity in which students interact with their peers and the teacher to hone their writing ability and acquire new writing skills. The teacher's role in the writing classroom is to assist students to carry out writing tasks, achieve the aims and objectives of the lesson, and solve problems via teacher's orientation and guidance (Daniels, 2002; Wertsch, 1991). The current study provided opportunities for peerevaluation. Peer-evaluation or peer-editing enhances students' writing skills as they can explicitly or implicitly comment on their peers' writing production so they can reinforce their writing skills and contribute to developing other students' writing skills as well (Yüce \& Aksu Ataç, 2019; Harutyunyan \& Poveda, 2018; Ekmekci, 2017; Min \& Xuemei, 2016). The concept of peer-editing in this study conforms to Vygotsky's social interaction concept.

\section{Research Objectives}

The study is guided by the following objectives:

1. To find out if there is any significant difference in the mean of the writing post-test scores of the control and experimental groups.

2. To find out if there is any significant difference in the mean of the writing pretest and the post-test scores of the experimental group.

\section{Literature Review}

Writing complements speech, it is, however, more complicated with numerous and long structures of organized sentences. These sentences are built on formal usage of vocabulary and punctuation, a process which is characterized by using alphabetical letters to convey ideas in an organized structure. This can be done utilizing a pen, a typewriter, a mobile phone, or a computer. One can use writing for many purposes such as writing for pleasure, sending personal letters, stimulating audiences' feelings, and predicting various needs of readers (Rijlaarsdam, Couzijn \& Bergh, 2004). According to Ralelon (1992), writing is a very pivotal skill as it forms a part of an individual's culture and it is done to preserve their ideas and thoughts. The systems of writing can be functional which is pertinent to the way it is used to show symbols of language which mirror people's way of thinking and culture (Olson, 1992).

\subsection{Teaching Writing at Tertiary Level}

According to Lea and Street (1998), learning at the tertiary level requires adjusting to new methods of understanding and new techniques of organizing 
information, and interpreting knowledge. Tertiary education fundamentally aims attention at honing students' academic writing competency as written language is substantially used to gauge students' performance (Hyland, 2006). Knowledge is obtained by students from various sources by going through others' writings. Hence, students are required to create acceptable academic texts exhibiting their understanding of knowledge and internationalization and also their capabilities to manipulate and synthesize them (Mondrano, 2015).

It is argued that higher education practices give academic writing great importance especially in assessing students' writing skills. Essay writing is deemed the most suitable assessment means of students' academic accomplishment (Bacha, 2002; Lillis, 2001; Krause, 2001). Thus, academic writing is essential to students' academic advancement at the tertiary level. To illustrate, Omani EFL learners are required to master content areas in many subjects such as business, social sciences, technical sciences, and mathematics where the language of the majority of the world's scientific literature in English. Hence, having good writing skills can enable students to successfully satisfy their academic demands and do well in their academic disciplines (Al-Badawi, 2011). Omani learners are expected to produce certain writing productions like summaries, essays, and mini-research projects. Nevertheless, experiences have always indicated that the vast majority of Omani learners encounter many difficulties in their writings. They are unable to produce meaningful sentences in isolation and they cannot organize them in texts (Alami, 2016; Al-Badi, 2015; Al Seyabi \& Tuzlukova, 2014). Further, students encounter many difficulties in essay writing. Students, for instance, are unable to generate and organize ideas, write a sound thesis statement, or use a wide range of vocabulary (Souidi \& Uba, 2020).

\subsection{Academic Writing}

Academic writing is distinguished by the organization and cohesion of ideas that allow sound connection between sentences and paragraphs. Effective use of language can help maintain the interest of readers to continue reading the entire text. The tracking of an evolving language, which is diverse, rich, and continuously developing in both meaning and use, is a constant process of experiences (Bailey, 2011).

\subsubsection{Approaches to Teaching Academic Writing}

Writing practice has many fundamental approaches. The literature review of this study elaborates on the writing approach which was employed by the current study.

\subsubsection{The Genre Approach}

Martin (1999) defines the genre as a communication process that incorporates an oriented goal for its members in a specific event of communication which is based on a certain social context. Academically, Harmer (2007) mentions that the genre approach requires learners to analyze and study a written text, and then they need to provide a written production akin to the text they have studied. The genre approach has many good characteristics. To illustrate, writing is considered a social activity by the genre approach. This concept stemmed from the social-cultural theory (Vygotsky, 1978). Knowledge according to the theory 
can be best formed when students work together; back each other to promote new ways of learning, to form, create, and reflect on new knowledge. Hence, participation and social interaction of members of the group significantly contribute to knowledge construction and development. Students, in the writing classroom, are stimulated to participate in various writing tasks and swap and negotiate meaning with classmates and teachers. Learning writing in this way can help students to have positive reinforcement about content, ideas, and the knowledge of linguistics in composing texts. The teacher's role in the genre approach is deemed more authoritative than autocratic (Rothery, 1996). Teachers provide students with support and methodical instruction via various writing activities to help them have a good grasp of the written genre.

The genre approach can be categorized into three classes (Cope and Kalantzis, 1993):

- Modeling: students are given a text and they are required to write a similar one.

- Construction: teachers and students in this stage work out the new text construction according to the information obtained from the model text.

- Independent Construction: students in this stage are expected to produce their writing making use of the information obtained from the model text.

The genre approach has been commonly used to improve students' writing performance (Al Azhar \& Maolida. 2019; Xu \& Li, 2018; Dirgeyasa, 2016; Rusinovci, 2015; Wang, 2013). For this reason, the genre approach has been considerably employed in this study module. The majority of the module chapters provided model texts, paragraphs, and essays for the students to familiarize them with the new writing tasks.

\subsection{Writing Process}

According to Fulwiler (1988), there are some fundamental stages of the writing process.

\subsubsection{Prewriting}

The prewriting stage, which is commonly called brainstorming, is the initial stage of the process of writing. It comprises all elements that students prepare before embarking upon any type of writing (Gustavsson \& Hedlund, 2011). Brainstorming encourages students to generate and organize their ideas logically (Chittooran, 2015) and also improves their writing ability (Abedianpour \& Omidvari, 2018; Amoush, 2015).

\subsubsection{Drafting}

Drafting is considered as the preliminary stage of writing. It is the stage of developing the notions that have been arranged and sorted in an outline that is produced during the prewriting stage of the writing process (Hedge, 2000). Drafting can help create an organized piece of writing (Coulmas, 2003).

\subsubsection{Revising}

In any writing process, revising is meant for rearranging the completed elements thoroughly in the writing production so it conforms to the intent and target of 
the writer. Consecutive revision of notes helps the writer add any necessary ideas or exclude any information which does not serve the purpose of the final draft (Cooper, 1999). During the revising stage, any ambiguous ideas or images become clearer when the writer makes certain corrections at the level of text flow (Folse, \& Pugh, 2010).

\subsubsection{Editing}

In the editing stage, the writer checks the piece of writing context for correctness and precision. It entails the correction and identification of errors such as punctuation, capitalization, grammar, and spelling (Harmer, 2004). Peer-editing is deemed one of the salient activities in the writing classroom. Peer editing enhances students' writing skills as it enables them to explicitly or implicitly comment on their peers' writing production so they can reinforce their writing skills and contribute to developing other students' writing as well (Siliwangi, 2019; Yüce \& Aksu Ataç, 2019; Harutyunyan \& Poveda, 2018; Ekmekci, 2017; Min \& Xuemei, 2016).

\subsection{Module or Instructional Design (ID)}

Instructional Design (ID) appertains to the standardized process in which training and educational programs propose to hone students' skills (Reiser \& Dempsey, 2007). The process embraces pinpointing the learners' needs, elucidating the end goal of instruction, and developing some "intervention" to aid in the transition (Duffy \& Cunningham, 1996). Instructional Design is the very heart of influential learning and teaching. Unless teachers organize, plan, and form teaching tasks, coincidental learning will be the outcome, and therefore the teacher might fail to gauge what has been accomplished in the classroom (Seel, 2017). Writing modules were found to be useful in improving students' writing skills more effectively than using conventional methods (Aswini \& Srinivasan, 2016). That is because writing modules help students develop their writing skills via incorporating interesting writing topics and students' learning needs (Belet Boyaci \& Güner, 2018; Al Azri \& Al-Rashdi, 2014; Arianie, 2017). Writing modules also help students provide significance to the learning process and maximize students' motivation by connecting the writing materials to their daily life (Chamba \& Gavilanes, 2018; Nematollahi \& Maghsoudi, 2015).

\section{Methodology}

The methodology gives a rigorous and particularized elucidation of the approach used to undertake the present research. It provides information on the research design, research participants, and selection of participants, research instruments, data analysis, and research procedures. The methodology is fostered in search of answers to the present research questions.

\subsection{Research Design}

The current study made use of a quasi-experimental design. According to Marsden and Torgerson (2012), the most common manner in the quasiexperimental approach is matching where a control group is assigned amid the non-treated population who share identical features as the experimental group. 
Hence, both the control and experimental groups are deemed alike and the results may be considered unbiased.

\subsection{Participants and Selection of Participants}

Convenience sampling technique was used to sample the research participants. Convenience sampling technique, which is a non-probability of sampling, was employed to select the target respondents primarily due to the ready availability of data. Convenience sampling was the ideal sampling technique applicable to the present study due to the geographical proximity to the researcher (Etikan, Musa \& Alkassim, 2016). The total number of students enrolled at both Sur Nursing Institute and The General Foundation Program Centre in Muscat was 160 students. To calculate the participants needed for the research, the researcher used an online sample size calculator. The calculated sample size was 70 students based on a confidence interval of 8.76 and a confidence level of $95 \%$. The participants of the current study also incorporated 2 EFL teachers. One teacher taught the experimental group and the other teacher taught the control group. The experimental group participants studied English at Sur Nursing Institute, while the control group studied English at The General Foundation Program Centre in Muscat. Both the control and experimental groups had similar demographic data concerning L1, gender, age, background education, and classroom contact hours in English. Both two groups were Arabic speakers. Each of the two groups involved 35 students, 8 males, and 27 females. The students had the same background education as all of them were secondary school leavers. The 2 EFL teachers had long experience in teaching English. The experimental group teacher worked for Sur Nursing Institute for 11 years, whereas the control group teacher worked for the Foundation Program Centre in Muscat for over 15 years.

\subsection{Research Instrument}

This study of quasi-experiential design employed two instruments: the pre-test and post-test. The two tests took the shape of essay writing. The essay was IELTS academic writing task 2 which gauged the writing performance of students in 4 prime criteria: coherence and cohesion, task achievement, grammatical range and accuracy, and lexical resource. Each criterion was assigned a band score between 1.0 and 9.0 (Appendix 1). The students were asked to write 250 words in 40 minutes about the relationship between technology and culture.

\subsection{Data Analysis}

Analysis of Covariance (ANCOVA) statistical test was used to gauge the effectiveness of the writing module on enhancing students' writing skills. ANCOVA was employed to control the writing pre-test scores statistically. Specifically, the pre-test aimed to pinpoint the differences that existed among the two groups (experimental and control) before the investigation. ANCOVA then was employed to statistically control the pre-test scores (Salkind \& Winter, 2017; Salkind, 2016; Jennings \& Cribbie, 2016; Delucchi, 2014). The covariate variable can minimize the inconsistency or the variability of the results measures. Hence, ANCOVA was the optimum statistical test to be employed in the current study because the pre-test (covariate variable) was controlled. 
Further, ANCOVA is a robust test that can maximize the power of the statistical tests (Jennings \& Cribbie, 2016; Salkind, 2016; Carter, 2010; Delucchi, 2014) as participants of both groups were determined via convenience sampling. Before performing the test, some assumptions were achieved as follows:

- The observation has to be independent. To illustrate, the target participants could only be either males or females, experimental group or control group.

- Concerning the dependent variable (DV) and covariate variable, the level of measurement had to be 'scale'. In the present study, the dependent variable was the students' writing performance after the intervention and the covariate variable was the writing pre-test.

- The dependent variable must be normally distributed. The researcher used Shapiro-Wilk as a test of normality because the number of participants was less than 50 .

- A linear correlation has to be present between the covariate variable and the dependent variable. Therefore, a scatter plot was employed to examine the correlation between the two variables.

- Homogeneity of regression slopes. The slopes of regression for both the covariate and dependent variables have to be indistinguishable. When the dependent variable intensified, the covariate variable must be intensified too.

- Homogeneity of variances was similar via the Levene's Test after performing the inferential test. F test was utilized to detect the correlation among the covariate and dependent variables.

\subsection{Procedures}

The current study was conducted during the second trimester. Before module delivery, the writing pre-test was administered to the experimental group by the module teacher, while the control group was given the pre-test by the writing syllabus teacher. The module in this study incorporated eleven chapters that were delivered abiding by the writing guidelines of The Omani Ministry of Health syllabus. The module ran for 44 hours, 4 hours were allotted for each chapter. The module used the genre approach to teach prewriting, writing, revising and peer editing, topic and controlling ideas, model paragraphs, organization of paragraphs within an essay, concluding sentence, supporting sentences, topic sentence, supporting details, grammar drills, and paragraph unity (Hajeid, 2018; Kamariah et al., 2018; Marulanda \& Martínez, 2017; Scholtz, 2016; Purwanto, 2016). Further, the module introduced pivotal grammar structures required for writing such as present simple, subject-verb-agreement, past simple, relative pronouns, articles, and order of adjectives. The module incorporated a CD ROM. The CD ROM provided supplementary writing materials for students (Cahyaningrum et al. 2015; Thakur, 2015; Dodd et al., 2015; Saragih, 2014). These were designed to help students improve their writing skills. Eventually, the module included many writing activities to arouse students' interest (Iswati, 2019; Kusumawati, 2017; Kumalasari \& Churiyah, 2017) and help them improve their writing performance. The control group studied the ministry's writing syllabus. The time allotted for the syllabus was 44 hours. The writing syllabus involved 8 units which taught students basic writing elements. The writing post-test was done after module delivery. 


\section{Results}

The results provide a comprehensive rundown of the study findings. The results describe the quantitative data analysis of descriptive statistics mean scores of both the pre-test and post-test to investigate the impact of the developed module on enhancing General Foundation Program students' writing skills. The following sections exhibit the results of both the control and experimental groups' writing pre-test and post-test. The initial assumptions for the writing pre-test and post-test were tested and achieved. Descriptive statistics are presented in section 6.1, whereas inferential statistical analysis is displayed in section 6.2.

\subsection{Descriptive Statistics}

There were 35 students in the experimental group and 35 students in the control group. Each of the two groups encompassed 8 male students and 27 female students.

\subsection{Inferential Statistical Analysis}

To investigate the significant differences between the groups' writing test scores, the researcher made use of ANCOVA (Analysis of Covariance).

As can be seen in Table 1 below, the writing post-test scores could be assumed to be normally distributed because the Shapiro-Wilk significant value was 0.200 . According to the group, the writing post-test was normally distributed as well. The Shapiro-Wilk value for the two groups was 0.200 .

Table 1: Test of Normality of the Writing Post-test

\begin{tabular}{lcc}
\hline & Statistics & Shapiro-Wilk \\
\hline Writing Post-Test & .095 & Sig. \\
Experimental group & .939 & .200 \\
Control group & .962 & .200 \\
\hline
\end{tabular}

NB. The significant value was more than 0.05 .

Figure 1 demonstrates that the two groups had a parallel linear connection between the scores of both the writing pre-test and the post-test.
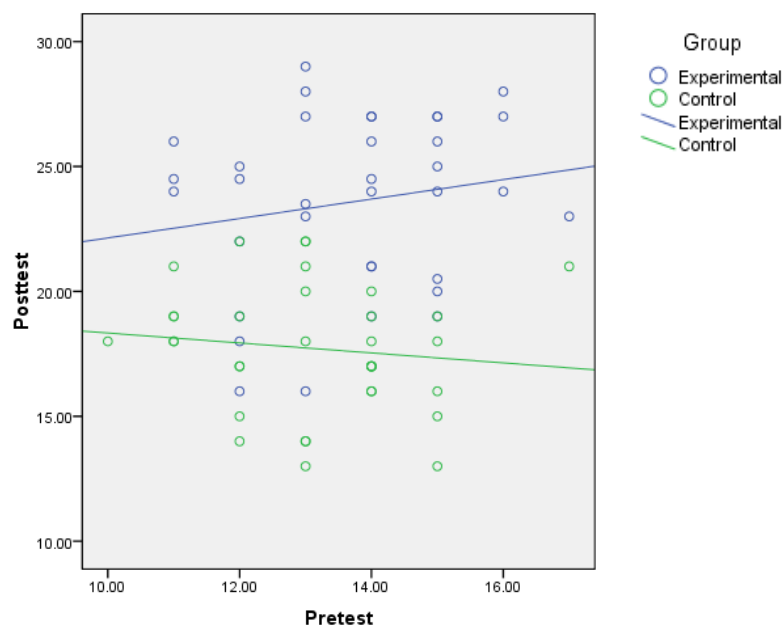

Figure 1: Scatter Plot Graph of the two groups' scores in the writing pre-test and posttest 
Homogeneity of regression slopes amid the dependent variable (writing posttest) and the covariate variable (writing pre-test) for both groups was similar. Table 2 confirms that no significant interaction was detected between the writing pre-test and the group. The interaction level was 0.233 which was more than .05 .

Table 2: Test Between-Subjects Effects Writing Post-Test as Dependent Variable

\begin{tabular}{llllll}
\hline & SS & df & MS & F & Sig. \\
\hline Group & 619.043 & 1 & 206.348 & 35.659 & 0.000 \\
Writing Pre-Test & 1.465 & 1 & 1.465 & 0.157 & 0.693 \\
Group* Writing Pre-Test & 14.080 & 1 & 14.080 & 1.512 & 0.223 \\
Error & 614.632 & 66 & 9.313 & & \\
\hline Total & 31083.250 & 70 & & & \\
\hline
\end{tabular}

The homogeneity of variances assumption was checked through Levene's test of homogeneity of variances. This test was used to test whether the samples had equal distribution. Equal variances across the samples are identified as homogeneity of variances. Homogeneity of variance is assumed when the value of $\mathrm{p}$ is greater than .05 (Muijs, 2004).

Table 3: Levene's Test of Equality of Error Variances ${ }^{a}$

\begin{tabular}{lcccc}
\hline & F & df1 & df2 & Sig. \\
\hline Writing Post-Test & 3.231 & 1 & 68 & 0.077 \\
\hline
\end{tabular}

According to Table 3 above, with an alpha level of .5, the p-value of writing post-test was 0.077 which was more than .05 , hence equal variances were assumed. Thus, the homogeneity of variances assumption for the two groups writing post-test was met.

As can be seen in Table 4 below, the Independent Samples t-test results with the assumption of equal variance confirmed that there was no significant difference in the writing pre-test scores between the two groups, $(68)=1.623, p=0.109$. Hence, it was assumed that the writing pre-test scores were equal for the two groups before the intervention.

Table 4: T-test for Equality of Means of Writing Pre-Test as Test Variable

\begin{tabular}{lccc}
\hline & $\mathrm{t}$ & $\mathrm{df}$ & Sig. \\
\hline Writing Pre-Test & 1.623 & 68 & .109 \\
\hline NB. Writing Pre-Test Scores of the two groups. & &
\end{tabular}

As Table 5 displays, the results confirmed that students' writing Pre-Test scores (covariate variable) did not have an effect on their Post-Test scores (dependent variable) with $F(1,67)=0.178$ and $p=0.674$. Since the writing pre-test scores were controlled, a significant difference was found between the two groups $\mathrm{F}(1$, $67)=60.618, p<0.05$. A large effect size (partial eta squared $=0.490$ ) was confirmed by the partial Eta Squared. According to Cohen (1988), 0.8 is considered a large effect size. Thus, the large effect size (0.490) signified that the variance in writing post-test scores of the students could be generally expounded by the writing module which was the independent variable in the study. The group was distinguished by the intervention of the writing module. 
Table 5: ANCOVA for Writing Post-Test Using Writing Pre-Test as Covariate

\begin{tabular}{llllll}
\hline & df & MS & F & Sig. & $\begin{array}{l}\text { Partial Eta } \\
\text { Squared }\end{array}$ \\
\hline Writing Pre-Test & 1 & 1.673 & 0.178 & 0.674 & 0.003 \\
Group & 1 & 568.821 & 60.618 & 0.000 & 0.490 \\
Error & 67 & 2.495 & & & \\
\hline Total & 70 & & & & \\
\hline
\end{tabular}

NB. Adjusted R Squared $=0.490$ computed through alpha value $=0.05$.

Table 6 below exhibits the standard deviation and means of the writing post-test of the two groups before and after adjusting the Pre-Test scores. ANCOVA results below revealed that the experimental group $(\mathrm{M}=23.585, \mathrm{SD}=3.477)$ scored considerably higher mean than the control group $(\mathrm{M}=17.714, \mathrm{SD}=2.538)$. There was a significant difference between the writing post-test scores of the two groups.

Table 6: Adjusted and Unadjusted Variability and Group Means for Writing Post-Test Using Pre-Test Scores as Covariate

\begin{tabular}{llllll}
\hline & & \multicolumn{3}{c}{ Unadjusted } & \multicolumn{2}{c}{ Adjusted } \\
\hline Group & $\mathrm{N}$ & $\mathrm{M}$ & $\mathrm{SD}$ & $\mathrm{M}$ & $\mathrm{SE}$ \\
\hline Experimental & 35 & 23.585 & 3.477 & 23.585 & 0.199 \\
Control & 35 & 17.714 & 2.538 & 17.714 & 0.204 \\
\hline
\end{tabular}

NB. Scores of Pre-Test in the model were gauged at the values of 13.414.

\section{Discussion}

The statistical results substantiated the significant difference between the control and experimental group's scores in the writing post-test after the intervention. The statistical results confirmed that the experimental group students scored significantly higher than the control group. This finding underlines the effectiveness of the module in improving students' writing skills. The research finding is in line with previous studies findings which revealed that effectively developed modules helped improve students' skills in generating ideas, opting for and selecting proper and relevant vocabulary for their writing, and maintaining cohesion, coherence, and paragraph unity (Hajeid, 2018; Kamariah et al., 2018; Marulanda \& Martínez, 2017; Scholtz, 2016; Purwanto, 2016).

The writing performance of the experimental group students improved significantly after the treatment. Statistical findings authenticated the significant difference between the experimental groups' writing pre-test and post-test. This underlines the effectiveness of the module in honing students' writing performance. The writing topics of the developed module were meticulously selected by the researcher based on their appropriateness and relevance to the students to assure optimal personal engagement and to motivate them to drip further into the module. This aroused students' interest and encouraged them to exert an effort to improve their writing skills (Iswati, 2019; Kusumawati, 2017; Kumalasari \& Churiyah, 2017). The module helped students to work collaboratively to carry out various writing tasks. Collaborative writing activities helped students share knowledge and learn from their peers (Saparuddin, Prasetyo \& Mahanal, 2018; Jeroen Janssen \& Wubbels, 2018; Bikowski \& 
Vithanage, 2016; Dowse \& Rensburg, 2015; Khatib, 2015; Nosratinia \& Nikpanjeh, 2015; Yeh, 2014). Peer-editing was of substantial significance in the module. The current research findings support previous findings which revealed that peer-editing enabled students to learn from other students' writing errors and reinforce their learning as well (Siliwangi, 2019; Yüce, 2019; Harutyunyan \& Poveda, 2018; Ekmekci, 2017; Min \& Xuemei, 2016). The findings of the present research conform to previous studies' results which addressed the significance of supplementary materials for EFL learners (Cahyaningrum et al. 2015; Thankur, 2015; Dodd et al. 2015; Saragih, 2014). The CD ROM which accompanied the module provided students with supplementary writing activities which helped them to improve their writing skills.

\section{Implications}

The present study has two types of implications: implications for research and implications for practice. To begin with, the current study used some theories to enhance students' writing skills. The present module was underpinned by the sociocultural theory of human learning (Vygotsky, 1978). The theory deems learning a social procedure. The prime abstraction of this theory is that social interplay significantly contributes to the progress of cognition. Vygotsky (1978) believes that there is an influential connection between learning and culturally organized experiences. The notion is very advantageous in learning and teaching since it addresses how learners' interplay becomes the most pivotal method by which learning and development take place. Students in this study interacted to carry out various writing tasks. To illustrate, students were encouraged to edit their peers' writing. Therefore, the theory was suitable for expounding and understanding the development of students' writing performance in the current study. The study has also implications for practice. The study has important implications particularly for teachers and educationalists in The Sultanate of Oman. This is because most of the educational institutions in Oman use international student textbooks that do not consider students' learning needs and thus fail to arouse students' interests (Ahmed \& Abouabdelkader, 2016; Al Ajmi \& Holi, 2014; Al-Mahrooqi \& Tuzlukova, 2014). Hence, developing a learning module that considers students' learning needs can help improve students' skills.

\section{Conclusion}

The study module effectually enhanced students' writing ability. The rigorous selection of the module topics contributed to honing students' writing performance. Moreover, the writing approaches which were employed by the module enhanced students' writing performance. The post-test results confirmed that the experimental group's writing ability was significantly improved. This was validated by the post-test results which revealed that the control group scored less than the experimental group. Further, there was a statistical difference between experimental group scores in both the pre-test and post-test. This underscores the module efficacy in addressing students' writing problems and increasing their achievement. The study confirms that efficient and systematic planning of modules can result in achieving learning objectives and supporting students' attainment. 
Before generalizing the conclusion, it is vital to stress the limitations of the study. It is argued that qualitative and quantitative study produces comprehensive and abundant data on the case research under examination. Nevertheless, the generalizability of the present outcomes is beyond the bounds of possibility which may be regarded as a limitation.

The current study raises opportunities for future research. It is suggested to conduct future studies that examine the effectiveness of the writing module on honing students' writing ability.

\section{References}

Abedianpour, S., \& Omidvari, A. (2018). Brainstorming strategy and writing performance: Effects and attitudes. Journal of Language Teaching and Research, 9(5), 1084-1094. doi:10.17507/jltr.0905.24

Abu-Faraj, B. (2015). The impact of Arabic language on producing fragments. European Scientific Journal, 11(29), 153-170. Retrieved from https:// eujournal.org/index.php/esj/article/view/6330

$\mathrm{Al}$ Ajmi, A. S., \& Holi, I. H. (2014). Collaborative writing in group assignments in an EFL/ESL classroom. English Linguistics Research, 3(2), 1-17. doi:10.5430/elr.v3n2p1

Ahmed, A., \& Abouabdelkader, H. (2016). Teaching EFL writing in the 21 $1^{\text {st }}$ century Arab world: Realities and challenges. London, England: Palgrave MacMillan.

Alami, M. (2016). Causes of poor academic performance among Omani students. International Journal of Social Science Research, 4(1), 126-136. doi:10.5296/ijssr.v4i1.8948

Al-Ani, W. (2017): Alternative education needs in Oman: Accommodating learning diversity and meeting market demand. International Journal of Adolescence and Youth. 22(3), 1-15. doi:10.1080/02673843.2016.1179204

Al Azhar, P. A., \& Maolida, E. H. (2019). Process genre approach in teaching writing narrative text: its implementation, benefits and obstacles. (a qualitative research at a senior high school in Cianjur). Journal of English Pedagogy, Linguistics, Literature, and Teaching, 7(2). doi:10.35194/jj.v7i2.656

Al Azri, R. H., \& Al-Rashdi, M. H. (2014). The effect of using authentic materials in teaching. International Journal of Scientific \& Technology Research, 3(10), 249-254.

Al-Badawi, H. S. (2011). The perceptions and practices of first year students' academic writing at the Colleges of Applied Sciences in Oman (Doctoral thesis, The University of Leeds, Leeds, England). Retrieved from https:/ / www.semanticscholar.org/

Al-Badi, I. (2015). Academic writing difficulties of ESL learners. Proceedings of WEI International Academic Conference (pp.104-135). Barcelona, Spain. Retrieved from https://www.westeastinstitute.com/wp-content/uploads/2019/03/EDUBARCELONA-2019.pdf

Al-Bereiki, S. A., \& Al-Mekhlafi, A. M. (2015). Spelling errors of Omani EFL students. Journal of Educational and Psychological Studies - Sultan Qaboos University, 9(4), 660676. doi:10.24200/jeps.vol9iss4pp660-676

Al-Issa, A. M. (2014). A critical examination of motivation in the Omani English language education system. Journal of Language Teaching and Research, 5(2), 406-418. doi:10.4304/jltr.5.2.406-418

Al-Mahrooqi, R., \& Tuzlukova, V. (2014). English communication skills and employability in the Arabian Gulf: the case of Oman. Pertanika Journal of Social Sciences $\mathcal{E}$ Humanities, 22(2), $473 \quad$ - $488 . \quad$ Retrieved from https://squ.pure.elsevier.com/en/publications/english-communication-skillsand-employability-in-the-arabian-gul

Al Seyabi, F., \& Tuzlukova, V. (2014). Writing problems and strategies: an investigative study in the Omani school and university context. Asian Journal of Social Sciences $\mathcal{E}$ 
Humanities, 3(4), 37-48. Retrieved from http://www.ajssh.leenaluna.co.jp/AJSSHPDFs/Vol.3(4)/AJSSH2014(3.4-05).pdf

Amoush, L. H. (2015). The impact of employing brainstorming strategy on improving writing performance of English major students at Balqa Applied University in Jordan. Journal of Education and Practice, 6(35), 88-92. Retrieved from https:/ / eric.ed.gov/ ?id=EJ1086359

Ancheta, R. F., \& Simagala, E. E. (2017). Grammar errors in written composition of selected level 3 students of Gulf College: Basis for remediation. International Journal of English Research, 3(2), 63-67. Retrieved from http://www.englishjournals.com/archives/2017/vol3/issue2/3-2-16

Arianie, M. (2017). Authentic material and interactive activities in EFL classroom. English Franca, 1(2), 115-134. doi:10.35961/salee.v1i02.109

Aswini, P., \& Srinivasan, R. (2016). The importance of using authentic materials in language learning. International Journal of English Language Literature and Humanities (IJELLH), 4(10), 392-399. Retrieved from https:/ /ijellh.com/OJS/index.php/OJS/article/download/1696/1642/

Bacha, N. N. (2002). Developing learners' academic writing skills in higher education: a study for educational reform. Language and Education, 16(3), 161-177. doi:10.1080/09500780208666826

Bailey, S. (2011). Academic writing: a handbook for international students. London, England: Routledge.

Belet Boyaci, S. D., \& Güner, M. (2018). The impact of authentic material use on development of the reading comprehension, writing skills and motivation in language course. International Journal of Instruction, 11(2), 351-368. doi:10.12973/iji.2018.11224a

Bikowski, D., \& Vithanage, R. (2016). Effects of Web-Based Collaborative Writing On Individual L2 Writing Development. Language Learning E Technology, 20(1), 79-99. doi:10125/44447

Cahyaningrum, D., Wahyuni, D., Sulistyawati, H., \& Kristiandi, H. S. (2015). Supplementary materials based on constructivism principles. International Journal of Social Science $\mathcal{E}$ Interdisciplinary Research, 1(1), 670-676. Retrieved from https://webcache.googleusercontent.com/

Chamba, M., \& Gavilanes, C. (2018). Authentic audio-visual material in the development of oral fluency in university intermediate English students. Literatura y Lingüistica, 39, 199-223. doi:10.29344/0717621x.39.2011.

Chittooran, M. M. (2015). Reading and writing for critical reflective thinking. New Directions for Teaching and Learning, 79-95. doi:10.1002/tl.20137

Cohen, J. (1988). Statistical Power Analysis for the Behavioural Sciences (2nd ed.). Hillsdale, USA: Lawrence Erlbaum Associates, Publishers.

Cope, B., \& Kalantzis, M. (1993). Background to Genre Teaching dalam. In B. Cope, \& M. Kalantzis (Eds.). The Power of literacy: A genre approach to teaching (pp. 249-260). London, England: Routledge.

Cooper, K. (1999). Strategies for essay writing. New York, USA: Routledge.

Coulmas, F. (2003). Writing systems: an Introduction to their linguistic analysis. Cambridge, England: Cambridge University Press. Retrieved from https:/ / www.cambridge.org/

Daniels, H. (2002). Vygotsky and pedagogy. London, England: Routledge.

Delucchi, M. (2014). Measuring student learning in social statistics: A pretest-posttest study of knowledge gain. Teaching Sociology, 42(3), 231-239. doi:10.1177/0092055X14527909

Dirgeyasa, W. (2016). Genre-based approach: what and how to teach and to learn writing. English Language Teaching, 9(9), 45-51. doi:10.5539/elt.v9n9p45 
Dodd, A., Camacho, G., Morocho, E., Paredes, F., Zuniga, A., Pinza, E., Toro, L., Vargas, A., Benitez, C., \& Rogers, S. (2015). The use of supplementary materials in English foreign language classes in Ecuadorian secondary schools. English Language Teaching, 8(9), 187-195. doi:10.5539/elt.v8n9p187

Dowse, C., \& Van Rensburg, W. (2015). "A hundred times we learned from one another" collaborative learning in an academic writing workshop. South African Journal of Education, 35(1), 1-12. doi:10.15700/201503070030

Duffy, T. M., \& Cunningham, D. J. (1996). Constructivism: implications for the design and delivery of instruction. In D. Jonassen (Ed.), Handbook of Research for Educational Communications and Technology (pp. 170-198). New York, USA: Simon \& Schuster Macmillan.

Ekmekci, E. (2017). The flipped writing classroom in Turkish EFL context: A comparative study on a new model. Turkish Online Journal of Distance Education-TOJDE, 18(2), 151-167. doi:10.17718/TOJDE.306566

Ellis, R. (2004). The definition and measurement of L2 explicit knowledge. Language Learning 54(2), 227-275. doi.org/10.1111/j.1467-9922.2004.00255.x

Etikan, I., Musa, S. A., \& Alkassim, R. S. (2016). Comparison of convenience sampling and purposive sampling. American journal of theoretical and applied statistics, 5(1), 1-4. doi:10.11648/j.ajtas.20160501.11

Folse, K. S., \& Pugh, T. (2010). Great writing 5: Greater essays. Boston, USA: Cengage Learning.

Fritz, M., Wetterich, S., Schirrmeister, L., Meyer, H., Lantuit, H., Preusser, F., \& Pollard, W. (2012). Analysis of self-recording in self-management interventions for stereotypy. Journal of Applied Behavior Analysis, 45(1), 55-68. doi:10.1901/jaba.2012.45-55

Fulwiler T. (1988). College writing. A personal approach to academic writing. (3 ${ }^{\text {rd }}$ ed.). New Hampshire, USA: Heinemann.

Gustavsson, J., \& Hedlund, M. (2011). The art of writing \& speaking. Statsvetenskapliga Föreningen. Retrieved from https://www.svet.lu.se/sites/svet.lu.se.en/files/artof-writing-speaking-2011.pdf.

Hajeid, M. R. (2018). Developing students essay writing. English Language Teaching, 11(12), 101-105. doi:10.5539/elt.v11n12p101

Harmer, J. (2004). How to Teach. Rotherham, England: Pearson Education.

Harmer, J. (2007). The practice of English language teaching. Harlow, England: Longman.

Harutyunyan, L., \& Poveda, M. F. (2018). Students' perception of peer review in an EFL classroom. English Language Teaching, 11(4), 138-151. doi:10.5539/elt.v11n4p138

Hedge, T. (2000). Teaching and learning in language classroom. Oxford, England: Oxford University Press.

Hyland, K. (2006). English for academic purposes: An advanced resource book. London, England: Routledge.

Iswati, L. (2019). Developing ADDIE model-based ESP Coursebook. Indonesian EFL Journal (IEFLJ), 5(2), 103-112. Retrieved from https://journal.uniku.ac.id/index.php/IEFLJ/article/view/1804

Jennings, M., \& Cribbie, R. A. (2016). Comparing pre-post change across groups: Guidelines for choosing between difference scores, ANCOVA, and residual change scores. Journal of Data Science, 14(2), 205-230. Retrieved from https://yorkspace.library.yorku.ca/xmlui/handle/10315/33240?

Jeroen Janssen, H., \& Wubbels, T. (2018) Collaborative learning practices: teacher and student perceived obstacles to effective student collaboration. Cambridge Journal of Education, 48(1), 103-122. doi:10.1080/0305764X.2016.1259389

Kamariah, A., Husain, D., Atmowardoyo, D., \& Salija, K. (2018). Developing authenticbased instructional materials for writing skill. Journal of Language Teaching and Research, 9(3), 591-599. doi:10.17507/jltr.0903.19 
Khalil, W., \& Yassin, A. (2015). Analysis of grammatical errors in writing of Omani learners of English as a foreign language at Nizwa University: (case study). Sudan Journal of Science and Technology, 16(2), 75-89. Retrieved from https://journal.uniku.ac.id/index.php/IEFLJ/index

Khatib, M. (2015). Languaging and Writing Skill: The Effect of Collaborative Writing on EFL Students' Writing Performance. Advances in Language and Literary Studies, 6(1), 203-211. Retrieved from https://eric.ed.gov/?id=EJ1127979

Krause, K. L. (2001). The university essay writing experience: a pathway for academic integration during transition. Higher Education Research \& Development, 20, 147-168. doi:10.1080/07294360123586

Kumalasari, N., \& Churiyah, M. (2017). Improving students skills in writing letters of commerce by developing correspondence module-based POE (predict-observeexplain). Jurnal Pendidikan Bisnis dan Manajemen, 3(1), 12-24. doi:10.17977/um003v3i12017p012

Kusumawati, F. P. (2017). Developing English learning material for speaking skill based on ADDIE. Premise Journal, 6(1), 29-41. doi:10.24127/pj.v6i1.805

Lea, M., \& Street, B. (1998). Student writing in higher education: An academic literacies approach. Studies in higher education, 23(2), 157-172. doi:10.1080/03075079812331380364

Lillis, T. (2001). Student writing: access, regulation, desire. London, England: Routledge.

Marsden, E., \& Torgerson, C. J. (2012). Single group, pre- and post-test research designs: Some methodological concerns. Oxford Review of Education, 38, 583-616. doi:10.1080/03054985.2012.731208

Martin, J. R. (1999). Factual writing: Exploring and challenging social reality. Victoria, Australia: Deakin University Press.

Marulanda, N. L., \& Martínez, J. N. (2017). Improving English language learners' academic writing: A multi-strategy approach to a multi-dimensional challenge. Gist Education and Learning Research Journal, 14, 49-67. https://eric.ed.gov/?id=EJ1146679

Min, G., \& Xuemei, S. (2016). Study on training strategies for effective peer review. CrossCultural Communication, 12(12), 40-44. doi:10.3968/9141

Mondrano, L. (2015). Importance of English as international medium of communication. Retrieved from https://www.linkedin.com/pulse/importance-englishinternational-medium-communication-lerma-mondrano

Mourssi, A. M. (2013). The efficacy of error analysis on second language learners' written accuracy: an empirical study in the context of Arab learners of English. Educational Research, 4(3) 249-256. Retrieved from http://www.interesjournals.org/ER

Muijs, D. (2004). Doing quantitative research in education with SPSS. London, England: Sage

Nematollahi, S., \& Maghsoudi, M. (2015). The effect of authentic versus non-authentic texts on upper intermediate Iranian EFL learners' vocabulary retention. English Language Teaching, 8(12), 112-123. doi:10.5539/elt.v8n12p112

Nosratinia, M., \& Nikpanjeh, N. (2015). Promoting foreign language learners' writing: Comparing the impact of oral Conferencing and collaborative writing. Theory and Practice in Language Studies, 5(11), 2218-2229. doi:10.17507/tpls.0511.05

Nouraey, P., Cuarteros, J. B., \& Khemiri, A. (2016). Omani Students' written errors and improvements with special reference to paragraph writing: a cross-sectional study. International Journal of English Language \& Translation Studies, 4(2), 120-125. Retrieved from https://www.academia.edu/29349682/

Nunan, D. (2003). Practical English Language Teaching. Singapore, Singapore: MCGrawHill Company.

Olson, C. B. (1992). Thinking writing: Fostering critical thinking through writing. New York, USA: Harper Collins Publishers. 
Parke, C. S. (2013). Essential First Steps to Data Analysis: Scenario-Based Examples Using SPSS Paperback. London, England: SAGE Publications Inc.

Purwanto, S. (2016). Improving Academic Writing Skills through Online Mode of TaskBased Assignments. English Language Teaching, 9(9), 74-84. doi:10.5539/elt.v9n9p74

Ralelon, B. (1992). Linguistics and its contribution to language teachers. Semarang: IKIP Semarang Press, in Mohamed, H. (2016). Algerian Arabic varieties speakers' errors in English writings "a contrastive error analysis study" (Doctoral thesis, University of Oran 2 Ahmed ben Ahmed, Oran, Algeria). Retrieved from https://www.ds.univ-oran2.dz > Doctoral Thesis The complete version

Reiser, R., \& Dempsey, J. V. (2007). Trends and issues in instructional design and technology. Kent, England: Prentice Hall.

Rijlaarsdam, G., Couzijn M., \& Van Den Bergh, H. (2004). The study of revision as a writing process and as a learning-to-write process. Dordrecht, Holland: Springer. doi.org/10.1007/978-94-007-1048-1_12

Rothery, J. (1996). Making changes: Developing an educational linguistics. In R. Hasan \& G.

Williams (Eds.), Literacy in Society. London, England: Longman.

Rusinovci, X. (2015). Teaching writing through process-genre based approach. US-China Education Review, 5(10), 699-705. doi:10.17265/2161-623X/2015.10.006

Sabtan, Y. M., \& Elsayed, A. M. (2019). Common writing errors among EFL students at Dhofar University in Oman: an analytical study. International Journal of English Linguistics, 9(2), 402-411. doi:10.5539/ijel.v9n2p402

Salkind, N. J. (2016). Statistics for people who (think they) hate statistics. London, England: Sage Publications.

Salkind, N. J., \& Winter, R. J. (2017). Study Guide for Psychology to Accompany Neil J. Salkind's Statistics for People Who (Think They) Hate Statistics. London, England: Sage Publications.

Saragih, E. (2014). Designing ESP Materials for Nursing Students Based On Needs Analysis. International Journal of Linguistics, 6(4), 59-70. doi:10.5296/IJL.V6I4.5983

Saparuddin, S., Prasetyo, T., \& Mahanal, S. (2018). Improving students' collaboration skills as teacher candidates through lesson study-based JiRQA learning strategy. PEOPLE: International Journal of Social Sciences, 4(2), 599-608. doi:10.20319/pijss.2018.42.599608

Scholtz, D. (2016). Improving writing practices of students' academic literacy development. Journal for Language Teaching, 50(2), 37-55. doi:10.4314/jlt.v50i2.2

Seel, N. M., Lehmann, T., Blumschein, P., \& Podolskiy, O. A. (2017). Instructional design for learning theoretical foundations. Rotterdam, Holland: Sense Publishers. doi:10.1007/978-94-6300-941-6

Siliwangi, I. (2019). The use of peer editing to improve students' writing skill. Professional Journal of English Education, 2(3), 275-281. doi:10.22460/project.v2i3.p275-281

Souidi, N. M., \& Uba, S. Y. (2020). Students' writing difficulties in English for business classes in Dhofar University, Oman. International Journal of Higher Education, 9(3), 86-97. doi:10.5430/ijhe.v9n3p86

Thakur, V. S. (2015). Using supplementary materials in the teaching of English: pedagogic scope and applications. English Language Teaching, 8(12), 1-6. doi:10.5539/ELT.V8N12P1

Thyab, R. A. (2016). Mother-tongue interference in the acquisition of English articles by L1 Arabic students. Journal of Education and Practice, 7(3), 1-4. Retrieved from https:/ / eric.ed.gov/?id=EJ1089791

Vygotsky, L. S. (1978). Mind in society: the development of higher psychological processes. Cambridge, USA: Harvard University Press. 
Wang, C. (2013). A study of genre approach in EFL writing. Theory and Practice in Language Studies, 3(11), 2128-2135. doi:10.4304/TPLS.3.11.2128-2135

Wertsch, J. V. (1991). Voices of the mind: a sociocultural approach to mediated action. Cambridge, USA: Harvard University Press.

Xu, X., \& Li, X. (2018). Teaching academic writing through a process-genre approach: A pedagogical exploration of an EAP program in China. The Electronic Journal for English as a Second Language, 22(2), 1-21. Retrieved from https:/ / eric.ed.gov/?id=EJ1187097

Yeh, H.-C. (2014). Exploring how collaborative dialogues facilitate synchronous collaborative writing. Language Learning $\mathcal{E}$ Technology, 18(1), 23-37. doi:10125/44348

Yüce, E., \& Aksu Ataç, B. (2019). Peer editing as a way of developing ELT students writing skills: An action research. Journal of Language and Linguistic Studies, 15(4), 1226-1235. doi:10.17263/jlls.668377

\section{Appendix 1}

ag

IELTS TASK 2 Writing band descriptors (public version)

\begin{tabular}{|c|c|c|c|c|}
\hline Band & Task Achievement & Coherence and Cohesion & Lexical Resource & Grammatical Range and Accuracy \\
\hline 9 & $\begin{array}{l}\text { - fully addresses all parts of the } \\
\text { task } \\
\text { - presents a fully developed } \\
\text { position in answer to the } \\
\text { question with relevant, fully } \\
\text { extended and well supported } \\
\text { ideas }\end{array}$ & $\begin{array}{l}\text { - uses cohesion in such a way that it } \\
\text { attracts no attention } \\
\text { - skilfully manages paragraphing }\end{array}$ & $\begin{array}{l}\text { - uses a wide range of vocabulary } \\
\text { with very natural and } \\
\text { sophisticated control of lexical } \\
\text { features; rare minor errors occur } \\
\text { only as 'slips' }\end{array}$ & $\begin{array}{l}\text { - uses a wide range of structures with full } \\
\text { flexibility and accuracy; rare minor errors } \\
\text { occur only as 'slips' }\end{array}$ \\
\hline 8 & $\begin{array}{l}\text { - sufficiently addresses all parts } \\
\text { of the task } \\
\text { - presents a well-developed } \\
\text { response to the question with } \\
\text { relevant, extended and } \\
\text { supported ideas }\end{array}$ & $\begin{array}{l}\text { - sequences information and ideas } \\
\text { - magically } \\
\text { - uses paragall aspects of cohesion well } \\
\text { appropriately }\end{array}$ & $\begin{array}{l}\text { - uses a wide range of vocabulary } \\
\text { - fluently and flexibly to convey } \\
\text { precise meanings } \\
\text { - skifully uses uncommon lexical } \\
\text { items but there may be } \\
\text { occasional inaccuracies in word } \\
\text { choice and collocation } \\
\text { - produces rare errors in spelling } \\
\text { and/or word formation }\end{array}$ & $\begin{array}{l}\text { - uses a wide range of structures } \\
\text { - the majority of sentences are error-free } \\
\text { inakes only very occasional errors or } \\
\text { inacies }\end{array}$ \\
\hline 7 & $\begin{array}{l}\text { - addresses all parts of the task } \\
\text { - presents a clear position } \\
\text { throughout the response } \\
\text { - presents, extends and } \\
\text { supports main ideas, but there } \\
\text { may be a tendency to } \\
\text { overgeneralise and/or } \\
\text { supporting ideas may lack } \\
\text { focus } \\
\end{array}$ & $\begin{array}{l}\text { - logically organises information and } \\
\text { ideas; there is clear progression } \\
\text { throughout } \\
\text { - uses a range of cohesive devices } \\
\text { appropriately although there may be } \\
\text { some under-lover-use } \\
\text { - presents a clear central topic within } \\
\text { each paragraph }\end{array}$ & $\begin{array}{l}\text { - uses a sufficient range of } \\
\text { vocabulary to allow some } \\
\text { flexibility and precision } \\
\text { - uses less common lexical items } \\
\text { with some awareness of style } \\
\text { and collocation } \\
\text { - may produce occasional errors } \\
\text { in word choice, spelling and/or } \\
\text { word formation }\end{array}$ & $\begin{array}{l}\text { - uses a variety of complex structures } \\
\text { - produces frequent error-free sentences } \\
\text { pus good control of grammar and } \\
\text { punctuation but may make a few errors }\end{array}$ \\
\hline 6 & $\begin{array}{l}\text { - addresses all parts of the task } \\
\text { although some parts may be } \\
\text { more fully covered than others } \\
\text { - presents a relevant position } \\
\text { although the conclusions may } \\
\text { become unclear or repetitive } \\
\text { - presents relevant main ideas } \\
\text { but some may be } \\
\text { inadequately } \\
\text { developed/unclear }\end{array}$ & $\begin{array}{l}\text { - arranges information and ideas } \\
\text { coherently and there is a clear overall } \\
\text { progression } \\
\text { - uses cohesive devices effectively, but } \\
\text { cohesion within and/or between } \\
\text { sentences may be faulty or mechanical } \\
\text { - may not always use referencing clearly } \\
\text { or appropriately } \\
\text { - uses paragraphing, but not always } \\
\text { logically }\end{array}$ & $\begin{array}{l}\text { - uses an adequate range of } \\
\text { vocabulary for the task } \\
\text { - attempts to use less common } \\
\text { vocabulary but with some } \\
\text { inaccuracy } \\
\text { - makes some errors in spelling } \\
\text { and/or word formation, but they } \\
\text { do not impede communication }\end{array}$ & $\begin{array}{l}\text { - uses a mix of simple and complex } \\
\text { sentence forms } \\
\text { - makes some errors in grammar and } \\
\text { punctuation but they rarely reduce } \\
\text { communication }\end{array}$ \\
\hline
\end{tabular}




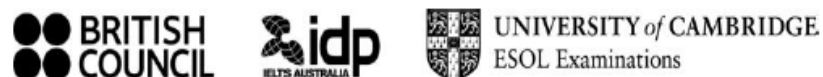

\begin{tabular}{|c|c|c|c|c|}
\hline 5 & $\begin{array}{l}\text { - addresses the task only } \\
\text { partially; the format may be } \\
\text { inappropriate in places } \\
\text { - expresses a position but the } \\
\text { development is not always } \\
\text { clear and there may be no } \\
\text { conclusions drawn } \\
\text { - presents some main ideas but } \\
\text { these are limited and not } \\
\text { sufficiently developed; there } \\
\text { may be irrelevant detail }\end{array}$ & $\begin{array}{l}\text { - presents information with some } \\
\text { organisation but there may be a lack of } \\
\text { overall progression } \\
\text { - makes inadequate, inaccurate or over } \\
\text { use of cohesive devices } \\
\text { - may be repetitive because of lack of } \\
\text { referencing and substitution } \\
\text { - may not write in paragraphs, or } \\
\text { paragraphing may be inadequate }\end{array}$ & $\begin{array}{l}\text { - uses a limited range of } \\
\text { vocabulary, but this is minimally } \\
\text { adequate for the task } \\
\text { - may make noticeable errors in } \\
\text { spelling and/or word formation } \\
\text { that may cause some difficulty } \\
\text { for the reader }\end{array}$ & $\begin{array}{l}\text { - uses only a limited range of structures } \\
\text { - attempts complex sentences but these } \\
\text { tend to be less accurate than simple } \\
\text { sentences } \\
\text { - may make frequent grammatical errors } \\
\text { and punctuation may be faulty; errors can } \\
\text { cause some difficulty for the reader }\end{array}$ \\
\hline 4 & $\begin{array}{l}\text { - responds to the task only in a } \\
\text { minimal way or the answer is } \\
\text { tangential; the format may be } \\
\text { inappropriate } \\
\text { - presents a position but this is } \\
\text { unclear } \\
\text { - presents some main ideas but } \\
\text { these are difficult to identify } \\
\text { and may be repetitive, } \\
\text { irrelevant or not well } \\
\text { supported }\end{array}$ & $\begin{array}{l}\text { - presents information and ideas but } \\
\text { these are not arranged coherently and } \\
\text { there is no clear progression in the } \\
\text { response } \\
\text { - uses some basic cohesive devices but } \\
\text { these may be inaccurate or repetitive } \\
\text { - may not write in paragraphs or their } \\
\text { use may be confusing }\end{array}$ & $\begin{array}{l}\text { - uses only basic vocabulary } \\
\text { which may be used repetitively } \\
\text { or which may be inappropriate } \\
\text { for the task } \\
\text { - has limited control of word } \\
\text { formation and/or spelling; errors } \\
\text { may cause strain for the reader }\end{array}$ & $\begin{array}{l}\text { - uses only a very limited range of structures } \\
\text { with only rare use of subordinate clauses } \\
\text { - some structures are accurate but errors } \\
\text { predominate, and punctuation is often } \\
\text { faulty }\end{array}$ \\
\hline 3 & $\begin{array}{l}\text { - does not adequately address } \\
\text { any part of the task } \\
\text { - does not express a clear } \\
\text { position } \\
\text { - presents few ideas, which are } \\
\text { largely undeveloped or } \\
\text { irrelevant }\end{array}$ & $\begin{array}{l}\text { - does not organise ideas logically } \\
\text { - may use a very limited range of } \\
\text { cohesive devices, and those used may } \\
\text { not indicate a logical relationship } \\
\text { between ideas }\end{array}$ & $\begin{array}{l}\text { - uses only a very limited range of } \\
\text { words and expressions with } \\
\text { very limited control of word } \\
\text { formation and/or spelling } \\
\text { - errors may severely distort the } \\
\text { message }\end{array}$ & $\begin{array}{l}\text { - attempts sentence forms but errors in } \\
\text { grammar and punctuation predominate } \\
\text { and distort the meaning }\end{array}$ \\
\hline 2 & $\begin{array}{l}\text { - barely responds to the task } \\
\text { - does not express a position } \\
\text { - may attempt to present one or } \\
\text { two ideas but there is no } \\
\text { development }\end{array}$ & $\begin{array}{l}\text { - has very little control of organisational } \\
\text { features }\end{array}$ & $\begin{array}{l}\text { - uses an extremely limited range } \\
\text { of vocabulary; essentially no } \\
\text { control of word formation and/or } \\
\text { spelling }\end{array}$ & $\begin{array}{l}\text { - cannot use sentence forms except in } \\
\text { memorised phrases }\end{array}$ \\
\hline 1 & $\begin{array}{l}\text { - answer is completely } \\
\text { unrelated to the task }\end{array}$ & - fails to communicate any message & $\begin{array}{l}\text { - can only use a few isolated } \\
\text { words }\end{array}$ & - cannot use sentence forms at all \\
\hline $\begin{array}{l}0 \\
\end{array}$ & \multicolumn{4}{|c|}{$\begin{array}{l}\text { - does not attend } \\
\text { : does not attempt the task in any way } \\
\text { - writes a totally memorised response }\end{array}$} \\
\hline
\end{tabular}

